\title{
The Future of Japan's Financial Market
}

\author{
Nobuyuki Kinoshita
}

\section{Introduction}

In this chapter I investigate the relationship between developments in Information and Communication Technology (ICT) and financial services and legislation, with a focus on the financial market. I then identify the problems with Japan's financial legislation.

The basic approach I employ is as follows: the services for financial transactions are built on the latest ICT, while the legal implications caused by the use of ICT are stipulated by the existing financial legislation. As the rapid development of ICT has made cross-industry and cross-border competition surrounding financial services extremely fierce, this has put enormous pressure on the financial industry to innovate their services. On the other hand, a nation's financial legislation might show remarkable delay because of the path-dependency of lawmaking and enforcement systems. The discrepancy between the rapid progress of ICT and delayed legislation varies by country, depending on the country's institutional structures. These national differences in turn reflect the relative competitiveness of financial industries and markets as a result of the varying speed and smoothness of financial service innovation.

Following this approach, first I explain the basic conditions regarding the relationship between ICT development and financial transactions. Put simply, the economic value produced by financial transactions basically consists of saving transaction costs. Transaction costs are basically information-processing costs, which are determined by the level of ICT. Second, I explain the grand design of financial legislation and the peculiarities of Japan's system. Generally speaking, the financial legislation of a country is composed of two categories. The first is financial legislation in a broad sense including basic legal systems such as bankruptcy laws. The second

\footnotetext{
N. Kinoshita $(\bowtie)$

Tokyo Financial Exchange Inc, Tokyo, Japan

e-mail: kinoshita@tfx.co.jp
} 
is the financial legislation in a narrow sense including regulatory systems such as security exchange laws. Third, I examine examples of the changes of financial transactions caused by ICT advancement in various countries and compare them with the development in Japan. Here I also survey previous delays in Japan's financial legislation.

Fourth, I focus on the current changes in financial markets by introducing examples of changes in financial markets around the world caused by advances in ICT. Former financial exchanges have transformed themselves into providers of financial market infrastructures. Global regulations have also changed in accordance with this transformation. In the fifth section I identify the challenges for Japan's financial legislation. I provide an example of the collective clearing system of over-the-counter (OTC) derivatives transactions, then I show the challenges of adapting to digital innovation. There are two main challenges: the first is how to design the overall financial legislation, and the second is how to enforce individual legislation. In the conclusion, I address the principle of "Legislative Facts," which is frequently invoked by the Japanese central government.

\section{Influence of ICT Development on Financial Transactions}

\subsection{Transaction Costs and Financial Transactions}

\section{Transaction Costs}

In this section I explain the relationship between ICT and financial transactions based on the theory of "Law and Economics".

First, let us consider the functions of "currency", which is the core concept of financial transactions. Economics points out that currency has three basic roles: unit of account, means of payment and means of storing value. On the other hand, the theory of Law and Economics stipulates that the basic function of institutions such as legislation and firms is the reduction of transaction costs, namely, search costs, negotiation costs, and enforcement costs. Currency can be understood as an institution. It provides a common infrastructure for transaction parties. Its three functions contribute to the reduction of transaction costs in the economic sphere.

The level of transaction costs depends on the information-processing costs, which are composed of the amount and the unit cost of information processing. The latter can be further decomposed into communication costs and analysis costs.

In this context, the role of currency and institutions is the reduction of the number of information-processing steps for the given economic activity of a country. Namely, currency and institutions work as the hub of an information processing network whose nodes are transaction parties. Information regarding individual economic transactions between the nodes are intensively collected at the hub and processed on the spokes between the hub and nodes. For example, a firm that purchases a good from a transaction partner pays the price via deposit transfer through the nation's bank system. 
By doing so, transaction partners can save the search cost, because they can trust the prudence of licensed banks. In addition, partners can save the negotiation and enforcement costs by employing reliable payment means. In this sense, currency and institutions are a kind of hub-and-spoke network.

A form of network contrasting to this hub-and-spoke network is a mesh network, where each transaction party communicates mutually and analyzes the counterparties of an economic transaction one by one. For example, a consumer might pay the price by handing cash directly to the retailer. By doing so, transaction partners can save the banking fee. As the transaction is face-to-face and the amount is relatively small, transaction costs of searching, negotiation, and enforcement are negligible in this case. For this kind of retail transaction, a mesh network using cash payment is preferable in terms of transaction costs.

Comparing the hub-and-spoke network with the mesh network, we can say that the former has the advantage saving transaction costs by reducing the number of information-processing tasks, but has the disadvantage of being vulnerable to threats against the hub. Once the hub of a network is damaged, the entire system malfunctions. The relative superiority and inferiority of both systems depend on the unit price of information processing.

\section{Influence of ICT Advances on the Information Network of Economic Spheres}

Applying this conceptualization, we can summarize the influence of ICT advances as the reduction of the unit cost of information processing. This cost reduction influences the choice of network by transaction parties. Namely, the transaction parties in the economic sphere always compare the different information processing costs of the hub-and-spoke network and the mesh network, and choose the network with a relatively cheaper cost. If the unit cost of information processing is generally reduced by advances in ICT, the relative advantage of the hub-and-spoke network vis-à-vis the mesh network is mitigated. It has less superiority in terms of reducing the number of information-processing steps because of the cheaper unit price, while its vulnerability at the hub remains unchanged despite ICT advances. This leads transaction parties to prefer the mesh network.

However, this influence varies depending on the kind of transaction cost. Namely, the weight of communication costs is the highest in regards to search cost, the lowest in enforcement cost, and medium in negotiation cost. ICT development so far has had more impact on communication costs than on analysis costs, so the shift of economic transactions toward a mesh network can be realized more remarkably in the area where search cost carries more weight. 


\subsection{The Unceasing Development of ICT ${ }^{1}$}

\section{Performance Improvement of Computer Hardware}

ICT development is not a recent phenomenon but has continued accelerating over the recent decades. When we analyze the influence of ICT advances on financial transactions, we should not be captivated by individual novel technologies but should always ascertain the long-term trend.

Advances in ICT are caused by the unceasing improvement of computer hardware performance. Concerning this phenomenon, there is the famous "Moore's Law". This rule of thumb states that the speed and capability of computers can be expected to double every one-and-a-half year as a result of increases in the number of transistors that a microchip can contain. This is an experimental principle but has been valid for several decades. As a result, the performance of computer hardware has improved exponentially. For example, the capacity of a tablet, which we can now purchase for a few hundred dollars, is equivalent to the capacity of a supercomputer that cost billions of dollars 30 years ago.

\section{Innovation of Software}

Based on this exponential improvement of hardware performance, various software innovations have been produced. No innovation is a mutation but an extension or combination of existing technologies. For example, the consensus algorithm, which is the core of block chain technology, is a combination of crypto technology and peer-to-peer (P2P) network technology. This is an epoch-making idea, but not novel technology. In block chain technology, transaction data is saved in the form of a cryptograph and disclosed in the P2P network. This cryptograph is checked via crypto technology by any node computer of the network. As this technology requires huge computing capacity, no one could realize this earlier. Indeed, the key challenge for block chain technology is how to overcome the scalability problem.

Another example is Artificial Intelligence (AI). This technology is nowadays in the spotlight, but not a recent development. Applying logical processing to computers has been a major subject of ICT for about 60 years, but there has been severe difficulty because of the insufficient capacity of computers. In the early AI, the logic was programmed in advance so that users had to input the predefined data exactly in order to operate the computer. In the second stage of AI, "expert systems" were employed to instruct the computer to set the logic by itself. However, it did not work satisfactorily at the time, because there was not enough volume of data to instruct the computer effectively. In the current stage, this problem might be solved by "deep learning" technology. The method of deep learning is similar to principal component analysis, which has long been established. However, the capacity of computers was insufficient at that time so that the application of this analysis was limited to the learning of a simple linear function. The performance improvement of hardware

\footnotetext{
${ }^{1}$ The following passages are based on Kinoshita (2019).
} 
has solved this problem and created the appropriate foundation for deep learning technology.

\section{Influence on the Future of Financial Services}

As these examples show, the performance improvement of computer hardware is indispensable for recent software innovations. Following Moore's Law, the improvement of hardware has accelerated software innovations unceasingly, and this has had a strong influence on business. Firms in all industries are aiming for increased customer satisfaction by utilizing ICT progress. As the performance of computer hardware continues to improve, this trend is irreversible.

In this way, the advancement of ICT has been so continuous and irreversible that it has also produced perpetual changes across the economic sphere without interruption. Currency and institutions are no exception. I believe we should recognize this fundamental trend; in the following section of this chapter, I project the future of financial markets based on the extension of this past trend.

\section{Financial Transactions and Financial Legislation}

\subsection{Grand Design of Financial Legislation}

\section{Composition of Financial Legislation}

As objects of financial transactions are contracts among transaction parties, the change of rights and duties of relevant parties caused by the transactions are prescribed by legislation. In addition, the rules among transaction parties and financial service providers are regulated in accordance with legislation. Therefore, the role of legislation is a matter of critical importance for financial transactions.

Financial legislation can be classified into two categories. The first is financial legislation in a broad sense. The second is financial regulatory laws. Hereafter I explain both categories in detail.

\section{Financial Legislation in a Broad Sense}

This category includes laws regarding corporate finance activities. In this context we can consider two kinds of capital providers. The first are human capital providers such as management and employees. The second are financial capital providers such as creditors and equity holders (Shishido, 2000). As for the latter, we can find liabilities to the creditors and capital for the sake of equity holders in the balance sheet. In the profit and loss account we can find the compensation for the management and employees, the payment of interest, and dividends to the financial capital providers. Here, currency works as a unit of measurement for financial statements.

Laws of debt and equity are examples of financial legislation in a broad sense. There are also many supplemental laws to these basic laws, such as securities laws 
starting with bills of exchange and promissory note laws, and corporate laws that govern the organizational design of equity-funded incorporated businesses.

Among them, bankruptcy laws have the closest relevance to financial transactions. They substantially govern the conversion process of debt to equity. That is, when a corporation falls into distress and has difficulty paying its debts, a bankruptcy procedure for this corporation would start. In this procedure, first the total value of all assets and businesses of the corporation is assessed. Then, the monetary rights of creditors to this corporation are restricted, subject to the assessed value. At the same time, they acquire managing rights to the corporation in the form of appointing the administrator and voting for the reconstruction plan. In this sense, we can regard bankruptcy procedures as collective debt equity conversions, which is a kind of financial transaction.

\section{Financial Legislation in a Narrow Sense}

Financial legislation in the narrow sense comes in two kinds. The first group regulates corporations as designated financial service providers. Banking acts are the typical example. These laws regulate the business scope or financial prudence and so forth of the target corporations, in order to secure public confidence regarding the solvency of corporations. The objects of the second group of regulatory laws are designated financial transactions. Securities exchange acts are a typical example. These laws regulate the methods of transactions, disclosures of information, and so on in order to secure the fairness of the transactions.

Comparing financial legislation in the narrow sense with the broad sense, the first difference is the way of enforcement. Legislation in the narrow sense requires high expertise to monitor the rapidly changing financial transactions and strong resilience to take appropriate measures regarding malpractice. Therefore, most advanced countries establish specialized bodies for financial regulation. The Securities and Exchange Commission of the United States is a typical example.

However, there are many variations of financial regulators among countries, from regulators of payment systems such as central banks to self-regulating bodies within industries such as security dealers' associations. This variation reflects several factors such as the infrastructure-like character of the financial system as well as the structure of financial legislation in the broad and narrow senses.

\subsection{Peculiarities of Japan's Financial Legislation}

\section{Peculiarity in Legislation}

As with other countries, Japan also has financial legislation in the broad sense such as the Law of Obligations, the Companies Act, and the Bankruptcy Act, and in the narrow sense such as the Banking Act and the Financial Instruments and Exchange Act (FIEA). 
Among the latter, the structure of the FIEA is characterized by its exhaustive specifications regarding the specific types of financial instruments, that are the object of regulation, except for general debt and equity, which are prescribed by financial legislation in a broad sense. The purpose of this act is fairness and transparency in the transactions of designated financial instruments. The FIEA imposes special regulations on the transaction parties of these designated financial instruments. The act also regulates the related service providers as financial exchanges or business operators of financial instruments. It requires a license for doing such businesses to handle designated instruments, imposes special duties on their business practices, and supervises their management. Specifically, the FIEA regulates every detail of financial exchanges, starting from the scope of business and including financial prudence.

These regulations are backed by criminal punishments. Even in the case of the Banking Act, if a provider violates a particular duty, the regulator would give an administrative order, and if the provider does not follow the order, the regulator would file criminal charges. Furthermore, the FIEA imposes direct criminal punishment for misconduct in the transactions of designated financial instruments. This is a sharp contrast to financial legislation in the broad sense, where the rights and duties of related transaction parties are principally adjusted through civil procedures.

These peculiarities have great impact on Japan's financial institutions and the financial industry. Under the principle of nullum crimen sine lege, ${ }^{2}$ the specification of the financial instruments must be clearly defined. This hindrance is particularly remarkable for the FIEA. Because of this stringent law-making process, Japan's financial regulations are hardly able to catch up with the rapidly changing financial transactions.

Sometimes we can observe a unique phenomenon in Japan where the behavior of a corporation's management is investigated by the prosecutor for potential violation of financial regulations before the respective issue is taken up by the board of directors as part of the typical corporate governance procedure. In this way, the grand design of Japan's financial legislation distorts the overall function of the country's financial market.

\section{Peculiarities in Enforcement}

The financial regulators in Japan are entirely governmental bodies financed by the state budget. As they have policing authority over financial service providers and transaction parties, the everyday practices of Japan's regulating officers are similar to those of police officers. They put emphasis on creating records, requesting reports and issuing orders. They have little monetary incentive to develop the financial market of the country.

The FIEA additionally created a special regulatory body called the 'Securities and Exchange Surveillance Commission'. This commission is, in sharp contrast to the American Securities and Exchange Commission (SEC), an investigating authority. Specifically, it has a special division for criminal investigation which is tasked with

${ }^{2}$ The translation of this maxim is "an act is not a crime if there is no law against it". 
collecting sufficient evidence until the prosecutor can strictly prove a violation. Sometimes this might require a considerably long period, potentially meaning that the misconduct being investigated may damage the function of the market significantly.

This character of Japan's regulators is quite different from that of other countries. For example, the main activities of the American SEC are the execution of civil lawsuits. In addition, it takes compensation from misconduct in the capital market on behalf of victim investors, similar to indemnity. Furthermore, a considerable part of their activities is financed by the financial industry. The equivalent market regulator in Germany, Bundesanstalt für Finanzdienstleistungsaufsicht (BaFin) has a similar character.

These differences of financial regulations in various countries derive from the legal system as a whole and the history of regulations in the respective countries. However, at the same time, they have great impact on the competitiveness of the financial industry and hence the overall economy. For example, when a new financial service using the latest ICT is introduced, in the United States the service is provided first, then the legal obstacles would be dealt with. In Japan, in contrast, it takes a long period before the FIEA is amended, or the new service is forced into an existing provision of the act. In Japan, the more strictly corporations follow regulations, the less competitive they become in the global financial world where "the early bird catches the worm".

\section{Innovation of Financial Services Caused by ICT Developments}

\subsection{Innovation of Financial Services}

As I mentioned earlier, the development of ICT has unceasingly accelerated based on the performance improvement of computer hardware, which has had a continuous and irreversible influence on the innovation of financial services for a long period of time. In the following section I provide two examples of this influence.

The first example is structured finance. In financial legislation in the broad sense, typical instruments of corporate finance are supposed to be debt as specified in the Law of Obligations or equity as regulated by the Companies Act. However, sometimes in actual corporate business, not only such ready-made alternatives but also order-made means of finance might be effective. For example, a corporation might segregate a particular asset for the purpose of effective risk management of various businesses. At the same time, a fund provider might prefer these hybrid products to conventional debt or equity in accordance with the preference of investors. Structured finance is the financial intermediation service used to satisfy the needs of both transaction parties. In the case of asset-backed finance, a service provider puts segregated assets into a special purpose vehicle (SPV) which is insulated from potential bankruptcy procedures of the original fund raiser. Then the service provider 
lets the SPV raise funds in the form of securities issuance corresponding to the preference of investors. In structured finance, the service provider utilizes ICT to set up the conditions of securities issued by the SPV, so as to provide more sophisticated services that can bring new revenue opportunities.

The second example of innovation caused by advances in ICT is an expansion of internet-based retail services and the consequent erosion of traditional payment services. Commercial transactions through the internet are exponentially growing, because the communication costs can be dramatically slashed. As the customer has no face-to-face interaction with a retailer, they desire retail and payment services to be provided as a single unit. Therefore, the integration of retail services and payment services through the internet has rapidly grown over the past 30 years and is currently growing exponentially. Particularly in China, this trend of utilizing advancements in ICT is accelerating, so that ICT-based tech giants have entered the market one after another. This development is not due to a plan by the Chinese central government, but it is the result of corporations' hard work in searching for revenue opportunities by utilizing advancements in ICT.

\subsection{Development of Financial Services in Japan}

Regarding these two examples, Japan has been lagging behind the global developments. In regards to structured finance, this service has been developed in the global market for 40 years. In Japan, however, it was first recognized as a meaningful financial service only in the late 1990s. This was accompanied by interest rate liberalization at first, but thereafter it continued to lag behind global developments. Even now, structured finance is less developed. For example, securitization and credit default swaps (CDS) were remarkably constrained by the poor corporate bond market. The corporate bond market is small in volume and very much biased toward high-rated bonds. There is no "junk bond" issued in Japan (Yoshii, 2009).

As for internet-based financial services, this was initiated as late as the second half of the 1990s in Japan. Moreover, at the beginning, convenience stores introduced banknotes-based services, including serving as receiving agents and providing ATM management services for banks. At that time, the Financial System Research Council considered the possibility of legislation governing new entries to internet-based financial services. However, around this same time, a major financial crisis occurred in Japan and the injection of governmental money into the banks became the main policy measure. It made newcomers prefer to have the status of a bank, as potential investors for newcomers might expect the possibility of receiving governmental assistance. In addition, in the subsequent amendment of the Act on Settlement of Funds, the upper limit was set for payment service operators other than banks. Today, making up for the delay compared with other countries regarding cashless payment has been set as an important policy target.

In the past, the most important reasons for this delay regarding the introduction of financial innovation were the interest rate and service fee regulations. Under the 
government's price control, financial service providers had no incentives to innovate. Today, however, I would highlight the problems with the grand design of financial legislation in Japan. The Bankruptcy Act is the first problem related to the delay in structured finance.

Japan's Bankruptcy Act has restrictive requirements for the distressed corporation to petition, in contrast to the United States. Additionally, insolvent corporations in Japan have no obligation to petition bankruptcy procedures, in contrast to Germany. Because of this, the start of most corporate reorganization in Japan is remarkably late so that there is little time to develop proper business and financial reorganization plans for the corporation. In this circumstance, there is little need for junk bonds and hence securitization and CDS.

The more serious hindrance for flexible financial innovation in Japan is the legal structure of financial regulations enforced by criminal punishments. Particularly, the FIEA has the largest influence. As mentioned above, the Act imposes regulations on transactions and service providers of designated financial instruments. As the regulations are backed by criminal punishments, the designation must be completely clear. Lawmakers must perfectly distinguish the designated instruments from common financial instruments. On the other hand, the typical financial innovations that utilize progress in ICT are hybrid financial instruments such as structured finance or integrated services with other industries such as retail or communication. The key for innovations is that they are cross-industry in nature. There is a sharp contradiction between the legal structure of the FIEA and flexible financial innovation in Japan. A clear example is the constraint on financial exchange businesses. Here, the Financial Services Agency based on its wide discretionary power granted by the FIEA and related Cabinet Office Ordinances requires that designation to precede business planning by financial exchanges. This constrains the competitiveness of Japan's financial markets and exchanges in the global market.

The advancement of ICT will accelerate in the future and will have more influence on financial innovation, so that the competition between relevant corporations will become intensified in cross-industry and cross-border contexts. If the Japanese government continues to adhere to the existing legislation in the future, innovation in Japan's financial industry might be left far behind its competitors.

\section{Recent Developments of Financial Markets}

\subsection{Recent Innovations in Financial Markets}

\section{Bankruptcy Procedures in China}

In this section I focus on the recent developments of financial markets. I begin with two examples of innovation in global financial markets. The first example is bankruptcy procedures in China. China has a bankruptcy law called the Bankruptcy and Reorganization Act, which is equivalent to a combination of Japan's Bankruptcy 
Act and Civil Rehabilitation Act. As Chinese courts in many provinces had utilized net-auctions in bankruptcy procedures, the People's Supreme Court of China announced that all notices and acceptances of bankruptcy procedures of all Chinese courts after August 2016 must be disclosed and processed on the internet. Following this announcement, around 30,000 procedures were processed on the internet in 2018.

When we visit the site National Enterprise Bankruptcy Information Disclosure Platform, ${ }^{3}$ we can find much information concerning the recruitment of administrators and sponsors, the auction of assets and so forth. Among them, sites for the auction of assets show detailed information about the individual assets of failed corporations, such as descriptions and characteristics of their real property. The auction is implemented on internet platforms by the administrators, based on the process and rules decided by the claimants committee. The only role of courts is the execution of the auction and guidance for the trustee.

The platform where net auctions of bankruptcy procedures take place is Ali Judicial Auction. ${ }^{4}$ As we visit this site, we can find detailed information of all kinds of assets. The investors have a strong interest in information on real assets in large cities, as ordinary articles are hardly put on sale in the overheated market. This development could be regarded as a fundamental change of bankruptcy procedure practices, which is the core of financial legislation in the broad sense.

\section{Clearing services of the European Commodity Clearing}

The second example is the clearing services of the European Commodity Clearing (ECC) for electricity futures transactions. This corporation belongs to the European Energy Exchange (EEX) group, but provides clearing services not only for transactions made with the EEX group but also to all commodity transactions including OTC transactions around the world. Specifically, the ECC offers a marketplace where 20 clearing members such as banks provide services to 370 non-clearing members.

Here we can see the remarkable difference with Japanese financial exchanges. First, the ECC is a CCP (Central Counter Party) for transaction parties of energy futures, but at the same time, it is a deposit-taking institution. The ECC is a bank supervised by the German regulator BaFin, based on the German Banking Act. In the legal structure of financial regulation in Germany, in contrast to Japan, the law for financial exchanges is separate from the law for security transactions, and the regulation of clearing services is distinguished from matching services (Mitsubishi UFJ Research \& Consulting, 2019). In addition, regarding the EEX group including the ECC, more than half of the business of the group consists of OTC transactions. The matching service of transactions is not so important for the exchange any more.

Furthermore, it is not required for the market participants of the EEX to be a registered German corporation. It is enough for them to be regulated by a nation's authority which has mutual recognition with the German regulator. This is the basis for the financial market to develop cross-border business in every part of the world.

\footnotetext{
${ }^{3}$ In Chinese: 全国企业破产重整案件信息网 (http://pccz.court.gov.cn/pcajxxw/index/xxwsy).

${ }^{4}$ In Chinese: 阿里拍卖 · 司法 (https://sf.taobao.com/).
} 
In fact, the ECC will provide clearing services for electricity futures transactions in Japan as well. ${ }^{5}$

\subsection{Change of the Role of Financial Market Infrastructures}

\section{A New Market Infrastructures Industry}

Earlier, the main roles of financial exchanges were matching services of offers and bids for standardized instruments and disclosing fair prices generated by the transactions. Nowadays, the role of these corporations is drastically changing from this conventional exchange for two reasons. The first reason is the economic one caused by developments in ICT. The second is the regulatory one as a measure for recurrence prevention in response to the last global financial crisis.

Advancements in ICT push all financial service providers to change their business models in association with the shift of information processing from a huband-spoke network to a mesh network. At the same time, ICT advances accelerate cross-industry and cross-border competition among ICT-related service providers so as to inspire innovation across all business areas, including financial services. The above-mentioned developments in bankruptcy procedures in China and clearing services in Europe are examples of this megatrend.

Regarding the function of existing financial exchanges, a significant phenomenon is the unbundling of their functions. Matching, clearing and price discovery were formerly united as sequential core functions of financial exchanges. Earlier these three functions were fulfilled by a single corporation, because informationprocessing costs can be saved by doing so. However, thanks to advancements in ICT, such information-processing costs have been reduced dramatically. We can enjoy matching services for economic transactions of all kinds of goods and services now, such as electronic commerce, the sharing economy, net auctions and so forth. The marginal economic value of matching services has drastically declined. There is little need for a specialized matching service of standardized financial instruments.

In addition, the implementation of transactions is supported by the various digital trustee businesses and even by the courts themselves, as in China. Therefore, the current emphasis of clearing services is not implementation itself but performance guarantee. This service helps transaction parties to hedge the counterparty risk caused by asymmetric information, which cannot be overcome by ICT advancements. Moreover, the price discovery function of financial exchanges is changing accordingly. The function became diversified, from the price schedule to the indicative price in accordance with various financial instruments.

\footnotetext{
${ }^{5}$ As for electricity futures in Japan, the Tokyo Commodity Exchange (TOCOM) will provide matching services and clearing services. This corporation has now been purchased by Japan Exchange (JPX), but still provides exchange services for certain commodity futures including electricity. Therefore, EEX and TOCOM will be direct competitors in clearing services of electricity futures in Japan.
} 
In this way, former financial exchanges have grown out of the erstwhile sequential business model from matching to clearing of designated financial instruments, and instead are now playing multiple roles for the transactions of a broad range of financial instruments. The transformation of former financial exchanges is corresponding to the shift of information processing from hub-and-spoke networks to mesh networks. Now they are becoming providers of financial market infrastructures, such as exchanges, clearing houses, and database providers.

\section{Blocking Systemic Risk}

Following the global financial crisis, regulatory authorities across the world have made sweeping financial regulation reforms including many recurrence prevention measures against systemic risk. The concentration of OTC derivatives transactions within Central Counter Parties (CCPs) is one of the most important measures. The focal point of this regulation is making use of the clearing function to block default contagion in the case of a market player's failure. The emphasis of this regulation of financial exchanges is not placed on the fair price discovery function, but on the solvency of the exchange system. The Principle for Financial Market Infrastructure was compiled by the Bank for International Settlements (BIS) and the International Organization of Securities Commissions (IOSCO) in 2012 for these reasons.

We can regard this development as a part of the megatrend caused by developments in ICT. First, financial markets have developed derivatives by using financial engineering based on ICT in order to save transaction costs. Derivatives transactions then greatly increased systemic risk as seen in the global financial crisis. On the other hand, the former core functions of financial exchanges were unbundled and reorganized. They are transforming themselves into providers of financial market infrastructures. In this new market infrastructure industry, clearing businesses became central and vital functions. Regulators expect them to act as a barrier against the contagion of market risks.

Regarding the new role of clearing businesses, a recent article has claimed that their role should not be limited only to derivatives, but also should be applied to other broad financial contracts (Schwarcz, 2018). According to this article, there are two reasons why the regulators wanted to concentrate the clearing of derivatives transactions within CCPs. The first was that derivatives tend to inflate transaction volumes as their costs are comparatively small given the expected economic effects. The second was that the contents and conditions of derivatives instruments are highly standardized so as to be suitable for collective clearing at a CCP. Because ICT progress provides similar conditions for financial contracts in general, the barrier function of CCPs should be employed to prevent the systemic risk concerning general financial transactions. 


\section{Challenges for Japan's Financial Legislation}

\subsection{Adjustment of Financial Legislation in Response to Advancements in ICT}

So far, I have discussed the global trends of financial markets and market infrastructure caused by ICT progress. Under these circumstances, financial legislation must be adjusted to the new reality. In particular, the regulation of the integrated provision of matching, clearing, and price discovery services must be sweepingly revised. The price discovery function that existing laws are designed for is the undifferentiated matching of standardized financial instruments. This is because at the time of its establishment the traditional system was confined by the relatively poor performance of ICT.

Every country has its own financial legislation. All systems have a bias toward the status quo caused by path dependency. The cross-country differences in financial legislation produce diverging effects on the competitiveness of nations' financial markets under the global progress of innovation. We find this problem particularly in Japan.

\subsection{Legal Foundation of the Collective Clearing System}

In the following section I present an example of the collective clearing system of OTC derivatives transactions. After the global financial crisis, regulatory authorities around the world established a consensus that OTC derivatives transactions should be concentrated within CCPs in order to block the contagion of the default risk of market players. A CCP makes it possible to collectively settle the credits based on the financial derivatives prior to bankruptcy procedures of a failed market participant. As every bankruptcy legislation has an equal treatment rule between creditors, the collective clearing system at CCPs needs an escape clause from the general rule of bankruptcy procedures.

Therefore, every country introduced a legal foundation for advance payment with a CCP. However, the concrete acts of legislation are quite different among concerned countries. In the United States, advanced payment to the financial exchange participants was permitted by the courts as they are not corporate-specific assets in the corporate reorganization procedure (Yamamoto, 2014). In Germany, the Bankruptcy Act was amended to allow advanced payments (Kansaku, 2018).

In Japan, in contrast to these countries, the FIEA was amended to provide a special scheme for financial derivatives transactions. At the same time, it requires business operators to concentrate financial transactions within the CCP in Japan (Article 15611-2 FIEA). The FIEA is one of the financial legislative acts in a narrow sense. This is quite unique from the point of view of the grand design of financial legislation, as a special law breaks the general conditions in order to maintain the effectiveness of a 
specific regulation. The coverage of this special treatment is limited to the financial instruments designated by the regulatory authority. From the point of view of business operators in Japan, the coverage of collective clearing was clearly decided by the authority ex-ante. That means the operators can enjoy high foreseeability, but they do not have enough incentive to modify the specifications of financial instruments spontaneously. Every detail must be clearly specified by the regulators in advance. ${ }^{6}$

However, Japan has a special clause in the Bankruptcy Act as well. This clause allows advance payment for the transactions of instruments that have a market price at exchanges and so forth (Article 58 of Bankruptcy Act) (Act No. 75 of 2004). This clause was established in the case that a bankruptcy administrator might have difficulty to set the timing of disposal for those instruments with volatile market prices. This clause is not backed by criminal punishment, so that the coverage can be decided flexibly in the course of civil procedures. Therefore, if this clause overrides the specific provisions of the FIEA, the constraints on the enlargement of the CCP's function would be more limited.

Regarding this question, legal experts support using this clause in the Bankruptcy Act in a wide range of financial instruments. An authority has written that "The clause can be applied to OTC transactions, as far as the price mechanism works in a fair and transparent manner. The transaction need not be made in the exchange." On the other hand, from an economic point of view, it depends on the balance between foreseeability and flexibility. In the period of less developed ICT, the former was more important as the strict standardization of financial instruments was indispensable for being accurately matched. However, advancements in ICT have made this constraint less important. In addition, it is useful for the barrier function to be applied to as many diverse instruments as possible.

In sum, as far as this example is concerned, financial legislation in the United States or Germany has remarkable superiority to that in Japan in the present situation. In the future, advances in ICT will continue to accelerate, so that the design of financial instruments and the business models of financial exchanges are expected to diversify further. For this reason, I believe Japan should reconsider the structure of its financial legislation. At least, the Japanese financial industry should apply the clause in the Bankruptcy Act to a broader range of financial transactions. In order to satisfy the needs for foreseeability about the coverage of collective clearing prior to bankruptcy procedures, soft-law measures would be desired, just like the treatment of trade creditors in The Guideline for Out-of-Court Workout. ${ }^{7}$

\footnotetext{
${ }^{6}$ This legislation is designed to be applied in the clearing of CDS. However, as CDS transactions are rare in Japan, this act supported mostly the clearing of OTC interest rates swaps.

7 The Guideline was established as a consensus of Japan's industrial firms and banks in 2001.
} 


\subsection{Challenges for Japan's Financial Legislation}

\section{Integrated Design of Financial Legislation}

The above-mentioned case is a typical example of the history of financial legislation in Japan. In Japan, developments in the legal environment regarding particular financial transactions have frequently been made through the amendment of financial legislation in the narrow sense (Takahashi, 2015). This development has constrained flexibility in financial services because these regulations rely on criminal punishment. Moreover, financial legislation tends to follow the inertia from the past because government officials have little incentive to adjust financial legislation to cutting-edge business models. The innovativeness of Japan's financial industry will suffer due to these problems, so that the financial market will be inferior to their overseas rivals.

A typical example of this weakness is the market for Collateralized Loan Obligation CLO) and CDS. Japan's institutional investors are major purchasers in the global CLO market, but the main issuers and main operators of CLO markets are not Japanese. There is no CLO market in Japan. According to my understanding, this is because the Japanese government amended only the FIEA in order to regulate CDS transactions but did not amend the Bankruptcy Act in order to give flexibility to the issuance of CLO. Under this legal structure, the function of the financial market to satisfy the demands of both issuers and investors cannot be fulfilled. The absence of a CLO market leads automatically to the lack of a CDS market, which is basically a measure to manage the credit risk of market instruments.

For these reasons, I believe that an integrated, comprehensive grand design for financial legislation is necessary for Japan's financial market to catch up with global innovations utilizing the rapid advancement of ICT.

\section{Smooth Enforcement of Financial Regulations}

The current businesses of the financial industry completely depend on computer systems. As ICT advancement is accelerating exponentially, the decision for system investment is becoming more essential for the management of financial service providers. It is particularly vital that they should take some time for computer system development before initiating new businesses.

From this point of view, the uncertainty of financial regulations would bring risk to earning expectations, while the delay of legislation would have negative effects on the creativity of the financial industry. Japan's method of financial legislation has a certain advantage in terms of the foreseeability of regulation, but a certain disadvantage in the delay in business innovation. As Japan's businesspeople are mostly risk-averse because of the harsh social penalty of business failure, the latter disadvantage has greater influence on management decisions in the financial industry. This baneful influence may be creating a vicious cycle with the industry's excessive dependence on financial regulation.

In this connection, we should pay attention to the concrete method of enforcement of financial regulations. The decisions of financial service providers for computer 
system development heavily depend on which type of enforcement is taken, ex-ante prevention or ex-post revision. In the case of ex-ante prevention, the management must incorporate the regulatory requirements into their computer system development in advance. This implies that every detail of the regulatory requirements must be clarified before the start of development, so as to provide longer lead time for new businesses. In contrast, in the case of ex-post revision, the regulator would charge the liability for consumer damages afterwards if the new business is implemented inappropriately. Therefore, the details of requirements and the details of financial regulations can be concurrently clarified.

In addition, we must pay attention to the fact that decisions about investments in new computer systems are made simultaneously with business partners. For example, financial market participants want to make decisions only after the financial exchange has started to develop its computer system. Under this situation, if Japan's regulator chooses the ex-ante prevention-type of enforcement, it would cause significant delays to financial innovation.

The principles of "First come, first served" and "Winner takes all" are dominant not only in the financial industry, but in all ICT-related industries. Every nation's regulator puts forth its best effort to enable the industry to take the lead. From these reasons, I believe that the enforcement of financial regulations in Japan should eliminate the ex-ante prevention-type of enforcement as much as possible and shift to the ex-post revision type. It would also mean that the principle of Japan's financial regulation should be shifted from criminal punishment to civil dispute resolution. The challenges for Japan's financial legislation and enforcement should be examined together in a holistic way.

\section{Closing Remarks}

In this article I have discussed the relationship between the advancement of ICT and financial services and legislation. However, the path dependency of Japan's institutions is not limited to financial legislation. I found that the response of Japan's institutions has almost always lagged behind industry innovations related to ICT advancement. Among several reasons for this delay, I believe that the principle of Legislative Facts is the most important one. This principle, which states that "legislation is possible only in the case its necessity is proven with substantial facts" is a basic rule for lawmakers.

This principle is surely fundamental under democratic regimes where parliament controls administration through legislative activities. Without this principle, ministries might propose too many bills, thereby preventing efficient discussion in the parliament. However, it is also certain that this principle dampens the creativity of related industries. They may give up on creating new businesses that would require the amendment of existing regulatory legislation, as normally it takes several years before the amendment is made. Meanwhile, overseas competitors might begin the 
business and occupy the market. This way, under this principle, the necessary conditions needed to push legislation cannot arise. This results in a strong bias for the nation's legislation to follow the status quo.

Sometimes ministries present the popularization of new kinds of transactions in overseas markets as supporting facts for pursuing legislation. However, Japan's industry will certainly lose to global competition in this competitive environment. Moreover, as the evidence used is mostly from English-speaking countries, it is common to miss out on innovative developments in other regions. For example, although the popularization of QR code payments in China have been common among citizens in Chinese cities for many years, it was not until a few years ago that Japan's mass media began writing reports about the cashless system in China.

It is expected that ICT advancement will continue to accelerate and that the competition in related industries will become even more intense in the future. Under these circumstances, the delay of legislation in Japan would have serious adverse effects on industries' competitiveness. I hope that Japan's lawmakers will acknowledge this situation and take prompt actions that demonstrate a commitment to proactive reform in a way that we have never seen before.

\section{References}

Hasanhō [Bankruptcy Act] Act No. 75 of 2004, as last amended by Act No. 71 of 2019.

Kansaku, H. (2018). Doitsu ni okeru tentō deribatibu torihiki kisei no dōkō- tōsanhō to no kankei wo chūshin toshite [Trends in regulation of OTC derivatives transactions in Germany: focusing on the relationship with bankruptcy law]. In Kin'yū hōmu kenkyūkai, Deribatibu torihiki ni kakaru shomondai to kin'yū kisei no arikata [Topics and regulatory issues on derivatives transactions] (pp. 78-109). https://www.zenginkyo.or.jp/fileadmin/res/news/news300350.pdf

Kinoshita, N. (2019). Dejitaru inobēshon to seichō senryaku [Digital innovation and growth strategy]. In Seichō senryaku hōsei kenkyūkai (2019), Seichō senryaku to kigyō hōsei-Inobēshon wo sokushin suru kigyō hōsei sekkei [Growth strategy and enterprise law: Legislation design to accelerate economic growth] (pp. 201-220). Shōjihōmu.

Kin'yū Shōhin Torihiki-Hō [Financial Instruments and Exchange Act], Act No. 25 of 1948, as last amended by Act No. 71 of 2019.

Mitsubishi UFJ Research \& Consulting (2019, March 30). Denryoku sakimono shijō no arikata ni kansuru chōsa hōkokusho [Study report on the electricity futures market]. https://www.meti.go. jp/meti_lib/report/H29FY/000116.pdf

Schwarcz, S. L. (2018). Central clearing of financial contracts: Theory and regulatory implications. University of Pennsylvania Law Review, 167, 1327-1373.

Shishido, Z. (2000). Dōkizuke no shikumi toshite no kigyō [The firm as incentive mechanism: The role of legal institutions]. Yūhikaku.

Takahashi, M. (2015). Wagakuni ni okeru shōkenka kanren hōsei no kiseki - Tokutei saikenhō kara minpō (saikenhō) kaisei made [The trajectory of securitization-related legislation in Japan: From the specified claims law to the amendment of the civil code (law of obligations)]. In Shisan ryūdōka ni kansuru chōsa kenkyū hōkokusho [Study Report on Asset Securitization] (Vol. 9, pp. 159-271). 
Yamamoto, K. (2014). Deribatibu torihiki nado no ikkatu seisan nettingu wo meguru saikin no giron - Kin'yū kiki go no beikoku deno giron wo fumaeta ichikōsatsu [Recent discussion on the collective clearing of derivative transactions]. Kin'yū Kenkyū, 33, 61-82.

Yoshii, K. (2009). Kurejitto shijō ni okeru kentō kadai: wagakuni shasai shijō no mondaiten, oyobi CDS no shūchū seisan kikan no setsuritsu to kisei no dōkō [Policy issues regarding the credit market: The establishment and regulation of Central Clearing Parties for credit default swaps], In the Financial Research Center, Kenkyūkai Hōkokusho - Kin'yū kiki go no kin'yū · Shihon shijō wo meguru kadai [Study report: Issues on post-crisis financial markets] (pp. 28-54). https://www. fsa.go.jp/frtc/kenkyu/20090722/01.pdf

Open Access This chapter is licensed under the terms of the Creative Commons AttributionNonCommercial-NoDerivatives 4.0 International License (http://creativecommons.org/licenses/bync-nd/4.0/), which permits any noncommercial use, sharing, distribution and reproduction in any medium or format, as long as you give appropriate credit to the original author(s) and the source, provide a link to the Creative Commons license and indicate if you modified the licensed material. You do not have permission under this license to share adapted material derived from this chapter or parts of it.

The images or other third party material in this chapter are included in the chapter's Creative Commons license, unless indicated otherwise in a credit line to the material. If material is not included in the chapter's Creative Commons license and your intended use is not permitted by statutory regulation or exceeds the permitted use, you will need to obtain permission directly from the copyright holder.

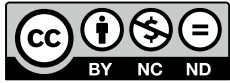

